\title{
The Concept of Law-Tied Pendent Jurisdiction: Gibbs and Aldinger Reconsidered
}

In any civil suit, a plaintiff may claim several violations of legal rights. Some of these claims may arise under federal law and thus be within the jurisdiction of the federal courts. ${ }^{1}$ Other claims may arise solely under state law and thus, absent diversity of citizenship, be cognizable only in state courts. ${ }^{2}$ When a plaintiff advances both state and federal claims, federal courts may apply the doctrine of pendent jurisdiction, ${ }^{3}$ which permits the courts to adjudicate state claims related to a substantial federal claim. In United Mine Workers v. Gibbs, ${ }^{4}$ the Supreme Court broadened the relationship permitted between the federal and state claims and thus opened the federal courts to numerous state claims that have no independent basis for federal jurisdiction. ${ }^{5}$

Since Gibbs was decided in 1966, the Supreme Court has carefully scrutinized the scope of the doctrine announced in that case only once. ${ }^{6}$ In Aldinger $v$. Howard ${ }^{7}$ the Court for the first time confronted the question of pendent party jurisdiction, which permits federal adjudica-

1. U.S. CoNsT. art. III, § 2; 28 U.S.C. $§ 1331$ (1970). Federal subject-matter claims may arise under other statutory grants. E.g., id. $\$ \S 1333,1337,1338$.

2. Article III makes a general division of jurisdiction between that based on a federal question and that based on the citizenship of the parties. The two heads of fecleral subject matter jurisdiction are (1) cases arising under federal law and (2) admiralty cases. The six heads based on the citizenship of the parties are (1) cases affecting ambassadors and other public ministers; (2) controversies in which the United States is a party; (3) controversies between two or more states; (4) controversies between citizens of different states; (5) controversies between a state and citizens of another state; and (6) controversies between a state or its citizens and a foreign state or its citizens. One head refers both to the citizenship of the parties and to the subject matter of the action: controversies between citizens of the same state claiming lands under grants of different states. U.S. CoNsT. art. III, $\$ 2$.

3. For discussions of pendent jurisdiction, sce ALI, Study of the Division of JuRIsdiction Between State and Federal Courts $\$ 1313$ (1969); 13 C. Wright, A. Miller \& E. Cooper, Federal Practice and Procedure $\$ 3567$ (1969) [hereinafter cited as Wright \& MIILler]; Schulman \& Jaegerman, Some Jurisdictional Limitations on Federal Procedure, 45 Y ALE L.J. 393 (1936); Shakman, The New Pendent Jurisdiction of the Federal Courts, 20 St.s. L. REv. 262 (1968); Note, The Evolution and Scope of Pendent Jurisdiction in the Federal Courts, 62 Colum. L. REv. 1018 (1962); Note. UMW v. Gibbs and Pendent Jurisdiction, 81 Harv. L. REv. 657 (1968); Comment, Pendent and Ancillary Jurisdiction: Towards a Synthesis of Two Doctrines, 22 U.C.L.A. L. REv. 1263 (1975).

4. 383 U.S. 715 (1966).

5. See note 87 infra.

6. But cf. Hagans v. Lavine, 415 U.S. $528,545-46$ (1973) (dictum) ("'II]t is evident from Gibbs that pendent state law claims are not always, or even most always, to be dismissed and not adjudicated. On the contrary, given advantages of economy and convenience and no unfairness to litigants, Gibbs contemplates adjudication of these claims."); note 8 infra.

7. 427 U.S. I (1976). 
tion of pendent state claims in which the parties are not the same as the parties to the federal claim. ${ }^{8}$ Pendent party jurisdiction had been developed in lower federal courts after Gibbs under the principles announced in that decision. ${ }^{9}$ The Aldinger Court reaffirmed the broad test for pendent jurisdiction established in Gibbs, but it attempted to restrict pendent party jurisdiction..$^{10}$

This Note argues that the Court's attempt to confine pendent party jurisdiction while preserving Gibbs was unsuccessful. An examination of the reasoning in Gibbs and Aldinger in light of the principles of limited jurisdiction of Article III reveals constitutional inadequacies in Gibbs. The Note offers a restrictive test for determining when to permit pendent jurisdiction-a test that comports with the mandate of Article III.

\section{From Gibbs to Aldinger}

\section{A. United Mine Workers v. Gibbs}

A coal company hired Paul Gibbs as a mine superintendent and gave him a contract to haul coal from the mine to a railroad terminal. Members of a local branch of the defendant union forcibly prevented the mine from opening. As a result, Gibbs lost his job as superintendent and could not perform his haulage contract.

Alleging violation of section 303 of the Labor-Management Relations Act (LMRA), ${ }^{11}$ which prohibits secondary boycotts, and unlawful conspiracy to interfere with his employment and haulage contracts, Gibbs brought suit against the union in federal district court. ${ }^{12}$ The trial court accepted jurisdiction over both the federal claim of illegal

8. In Moor v. County of Alameda, 411 U.S. 693 (1973), the Court also considered the problem of pendent party jurisdiction, but it declined to rule whether the federal courts have power to hear pendent party claims. Id. at 710-17. The Court instead affirmed the discretionary dismissal of the pendent party claim. Id. at 715. Cf. Philbrook v. Glodgett, 421 U.S. 707 (1975) (Court will not decide if pendent party jurisdiction extends to Secretary of HEW where substantive issue could have been decided without him and Secretary stated he would comply with decision). For discussions of pendent party jurisdiction, see 13 Wright \& Mirler, supra note 3, at 457-62; Fortune, Pendent JurisdiclionThe Problem of "Pendenting Parties," 34 U. PIrT. L. Rev. 1 (1972); Comment, Aldinger v. Howard and Pendent Party Jurisdiction. 77 Colum. L. Rev. 127 (1977); Comment, Federal Pendent Subject Matter Jurisdiction-The Doctrine of United Mine Workers v. Gibbs Extended to Persons Not Party to the Jurisdiction-Conferring Claims, 73 Colum. L. Rev. 153 (1973); Note, The Impact of Aldinger v. Howard on Pendent Party Jurisdiction, 125 U. PA. L. Rev. 1357 (1977).

9. See pp. 633-36 infra.

10. 427 U.S. at 14.

11. 29 U.S.C. $\$ 187$ (1970).

12. Gibbs v. United Mine Workers, 220 F. Supp. 871 (E.D. Tenn. 1963), aff'd, 343 F.2d 609 (6th Cir. 1965), rev'd, 383 U.S. 715 (1966). 
secondary boycott and the state claim of unlawful conspiracy. ${ }^{13}$ The Sixth Circuit affirmed. ${ }^{14}$

The Supreme Court took the opportunity on certiorari to redefine the doctrine of pendent jurisdiction. ${ }^{15}$ When it had last addressed the

13. 220 F. Supp. at $880-81$.

14. Gibbs v. United Mine Workers, 343 F.2d 609 (6th Cir. 1965), rev'd, 383 U.S. 715 (1966).

15. The origin of pendent jurisdiction has been traced to Osborn v. Bank of United States, 22 U.S. (9 Wheat.) 738 (1824). ALI, supra note 3. at 208; 13 WWRIGHT \& MIILER, supra note 3, at 439. In Osborn, Chief Justice Marshall stated:

[W] hen a question to which the judicial power of the union is extended by the Constitution, forms an ingredient of the original cause, it is in the power of Congress to give the Circuit Courts jurisdiction of that cause, although other questions of fact or of law may be involved in it.

22 U.S. (9 Wheat.) at 823. Since the validity of the Bank's existence and its power to transact business were at least implicit questions in every case, and since those questions depended on its charter of incorporation, a federal law, the Court held that the federal courts could have jurisdiction over all suits involving the Bank. Id.

The language in Osborn could support a very broad federal jurisdiction. Whenerer an entity can trace its existence or its powers to federal law, it may sue and be sued in federal court. Such jurisdiction was actually upheld in the Pacific Railroad Removal Cases, 115 U.S. 1, 11-14 (1885). But this broad reading of Osborn was rejected by the Supreme Court in Romero v. International Terminal Operating Co., 358 U.S. 354, 379 n.50 (1959), and by Congress in the Judiciary Act of 1925, ch. 229, $\S 12,43$ Stat. 941 (present version at 28 U.S.C. $\$ 1349$ (1970)).

Other statements in the Osborn opinion, however, imply a narrower view of federal jurisdiction. References to the "character of the cause" and the "origin" of the action, 22 U.S. (9 Wheat.) at 822,825 , indicate that Marshall was using the "source of law" test that was later used to determine whether a case arises under federal law; that is, a case arises under federal law if federal law creates the right whose vindication is sought, see note 70 infra. Although Marshall's unusual application of this test may be disputed, it may have resulted from an attempt to protect the Bank. See Textile Workers v. Lincoln Mills, 353 U.S. 448, 473 (1957) (Frankfurter, J., dissenting); C. WRIGHT, The LAw OF Federal Courts $78-79$ (3d ed. 1976).

Siler v. Louisville \& N.R.R., 213 U.S. 175 (1909), has also been cited as a significant development in the evolution of pendent jurisdiction. 13 WRIGHT \& MILLER, supra note 3 , at 440. Siler, however, is consistent with a narrow reading of Osborn. In Siler a state order regulating railroad freight rates was attacked as unauthorized under state law and as unconstitutional under federal law. The Supreme Court stated:

The Federal questions, as to the invalidity of the state statute because, as alleged, it was in violation of the Federal Constitution, gave the Circuit Court jurisdiction, and, having properly obtained it, that court had the right to decide all the questions in the case, even though it decided the Federal questions adversely to the party raising them, or even if it omitted to decide them at all, but decided the case on local or state questions only.

213 U.S. at 191. The state regulation was held invalid on state grounds; the Court declared this course preferable to an unnecessary determination of federal constitutional questions. Id. at 193.

The Siler holding should be regarded as an attempt to refrain from rendering advisory opinions. An actual case or controversy would only have been presented if the state regulations were actually valid under state law. If the Court had merely assumed the regulation's validity for the purpose of deciding the constitutional question, it would have been rendering an advisory opinion. United States v. Fruehauf, 365 U.S. 146, 157 (1961). A decision on the state question was thus necessary to a decision on the Fourteenth Amendment question; if the regulation were unauthorized under state law, there would have been no federal question to decide. 
doctrine in Hurn v. Oursler, ${ }^{16}$ the Court had distinguished a nonfederal ground supporting a federal cause of action from a nonfederal cause of action:

The distinction to be observed is between a case where two distinct grounds in support of a single cause of action are alleged, one only of which presents a federal question, and a case where two separate and distinct causes of action are alleged, one only of which is federal in character. In the former, where the federal question averred is not plainly wanting in substance, the federal court, even though the federal ground be not established, may nevertheless retain and dispose of the case on the non-federal ground; in the latter it may not do so upon the non-federal cause of action. ${ }^{17}$

In defining cause of action as the violation of a legal right, ${ }^{18}$ Hurn quoted with approval Baltimore Steamship Co.v. Phillips ${ }^{19}$ to the effect that " '[a] cause of action does not consist of facts,' . . . 'but of the unlawful violation of a right which the facts show." "20

Calling this test "unnecessarily grudging," the Gibbs Court held that pendent jurisdiction exists whenever a substantial claim arises under federal law and the relationship between that claim and the state claim is such that the two form "one constitutional "case." "21 The Court then defined the scope of an Article III "case":

The state and federal claims must derive from a common nucleus of operative fact. But if, considered without regard to their federal or state character, a plaintiff's claims are such that he would ordinarily be expected to try them all in one judicial proceeding, then, assuming the substantiality of the federal issues, there is power in the federal courts to hear the whole..22

16. 289 U.S. 238 (1933). Hurn itself did not use the term "pendent jurisdiction." The term first appeared in 1946 in Best \& Co. v. Miller, 67 F. Supp. 809 (S.D.N.Y. 1946). Prior to Best, it was known as the Hurn v. Oursler doctrine. E.g., Zalkind v. Scheinman, 139 F.2d 895 (2d Cir. 1943), cert. denied, 322 U.S. 738 (1944).

17. 289 U.S. at 246 (emphasis in original). In Hurn the petitioners' suit alleged a federal claim of copyright infringement and two state common law claims of unfair competition. The Court permitted jurisdiction over the federal claim and one of the state claims because they constituted one cause of action-the "violation of a single legal right, namely, the right to protection of a copyrighted play." Id.

18. Id.

19. 274 U.S. 316 (1927).

20. Id. at 321, quoted in 289 U.S. at 246. The Court continued: " ' $t$ ] variety of the facts alleged do not establish more than one cause of action so long as their result, whether they be considered severally or in combination, is the violation of but one right by a single legal wrong." " 274 U.S. at 321, quoted in 289 U.S. at 246. Relying on Phillips, the Hurn Court thus focused on rights, not on facts, in determining jurisdiction.

21. 383 U.S. at 725 .

22. Id. (emphasis in original). 
Having redefined the "power" of federal courts to hear pendent claims, the Court placed a second constraint on the exercise of pendent jurisdiction: application of the doctrine is within the federal court's discretion. ${ }^{23}$ Specifically, the Court held that even if the state and federal claims arise from a common nucleus of operative fact, the federal court should exercise pendent jurisdiction only if judicial economy, fairness to the litigants, and comity with state law will be served.2t

The Court found support for its test in the resolution of the longstanding debate concerning the definition of "cause of action." The Court noted that in 1933, when Hurn was decided, the meaning of cause of action was in dispute. Some viewed cause of action as the violation of a legal right. ${ }^{25}$ This was the definition adopted by the Hurn Court. Others defined cause of action as a factual transaction out of which any number of legal wrongs might arise. ${ }^{26}$ The Gibbs Court regarded the adoption of the Federal Rules of Civil Procedure, which allow joinder of claims that arise from the same transaction, as marking the end of the controversy in favor of the transactional def-

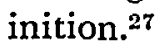

\section{B. Aldinger v. Howard}

Monica Aldinger, a clerical employee, was fired from her job in the county treasurer's office. The treasurer informed her that although her performance had been " 'excellent," " she would be discharged because she was " 'living with [her] boyfriend." "2s Claiming violations of her substantive and procedural constitutional rights, Aldinger brought suit in federal district court against the treasurer, other county officials,

23. Id. at 726 .

24. Id. The Court sought to guide the lower federal courts' exercise of discretion by discussing a number of jurisdictional possibilities. Thus, if the federal claim were dismissed before trial, or if the state claim predominated in terms of proof, remedy sought, or scope of issues raised, then the state claim should be dismissed. But if the state claim were closely tied to questions of federal policy, then the argument for pendent jurisdiction would be particularly strong. If taking jurisdiction over the state claim would likely cause jury confusion, however, pendent jurisdiction should be denied. Id. at 726-27.

25. E.g., J. Pomeroy, Code Remedies $\$ 347$ (4th ed. 1904); Gavit, A Pragmatic Definition of the "Cause of Action"?, 82 U. PA. L. REv. 129 (1933).

26. Judge Charles Clark was the foremost advocate of the transactional view. See C. Clark, Code Pleading 127-47 (2d ed. 1947); Clark, The Cause of Action, 82 U. PA. L. REv, 354 (1934). The transactional definition made its appearance in the Field Code of 1848. F. James \& G. Hazard, Civil Procendure 19 (2d ed. 1977). It is currently found in the Restatement (Second) of Judgments $\$ 61$ (Tent. Draft No. 1 1973). The Gibbs Court adopted the transactional definition when it required a common nucleus of opcrative fact, 383 U.S. at 725 .

27. 383 U.S. at 724 \& n.10 (citing, inter alia, FED. R. Crv. P. 18-20).

28. Aldinger v. Howard, 427 U.S. 1, 3 (1976). 
and the county under 42 U.S.C. $\$ 1983$ and 28 U.S.C. $§ 1343(3) .{ }^{20}$ Aldinger also asserted a state claim against the county resting upon state statutes waiving the county's sovereign immunity and providing for the county's vicarious liability for the torts of its officials. ${ }^{30}$

The district court dismissed the federal claim against the county on the ground that the county was not a "person" against whom suit may be brought under section 1983. Since there was no federal basis for jurisdiction over the county, the court held that it had no power to exercise pendent jurisdiction over the state claim against the county, even though a federal claim against the individual county officials remained. ${ }^{31}$ The Ninth Circuit affirmed. ${ }^{32}$

On appeal to the Supreme Court, Aldinger argued that her pendent party claim against the county satisfied the test for pendent jurisdiction established in Gibbs. ${ }^{33}$ The Court reviewed the development of pendent jurisdiction and found Gibbs consistent with Article III. ${ }^{34}$ But the Court found Gibbs distinguishable on two grounds from the pendent party claim in Aldinger..$^{35}$ The first difference was that the addition in Aldinger of "a completely new party"-that is, the county ${ }^{36}$ - "would run counter to the well-established principle that federal courts, as opposed to state trial courts of general jurisdiction, are courts of limited jurisdiction marked out by Congress." ${ }^{37}$ The proposition that the federal courts are courts of limited jurisdiction, however, does little more than restate the problem. Granting the unmistakable validity of this maxim, ${ }^{38}$ the extent of that jurisdiction remains to be

\section{Section 1983 provides:}

Every person who, under color of any statute, ordinance, regulation, custom, or usage, of any State or Territory, subjects, or causes to be subjected, any citizen of the United States or other person within the jurisdiction thereof to the deprivation of any rights, privileges, or immunities secured by the Constitution and laws, shall be liable to the party injured in an action at law, suit in equity, or other proper proceeding for redress.

42 U.S.C. $\$ 1983$ (1970). Section $1343(3)$ gives the district courts original jurisdiction over actions

to redress the deprivation, under color of any State law, statute, ordinance, regu-

lation, custom or usage, of any right, privilege or immunity secured by the Constitution of the United States or by any Act of Congress providing for equal rights of citizens or of all persons within the jurisdiction of the United States.

28 U.S.C. $\$ 1343(3)(1970)$.

30. WASH. REv. CODE $\$ 4.08 .120$ (1974).

31. The district court decision is recounted in the opinion of the court of appeals. Aldinger v. Howard, 513 F.2d 1257 (9th Cir. 1975), aff'd, 427 U.S. 1 (1976).

32. 513 F.2d 1257, 1258 (9th Cir. 1975).

33. Brief for Petitioner at 19-20, Aldinger v. Howard, 427 U.S. 1 (1976).

34. 427 U.S. at I4.

35. Id.

36. Id. at 15 .

37. Id.

38. U.S. ConsT. art. III, $\S 2$; Hodgson v. Bowerbank, 9 U.S. (5 Cranch.) 303 (1809);

The Federalist No. 81 (A. Hamilton) 541, 552 (J. Cooke ed. 1961). 
delimited. That the Court itself regarded this first difference as superfluous is indicated by its refusal later in the opinion to hold all pendent party jurisdiction impermissible. ${ }^{39}$

The second basis for distinguishing Gibbs was that contrary inferences could be drawn from the congressional conferrals of jurisdiction in the two cases. The Aldinger Court observed that in the jurisdictional statutes applicable to Gibbs, Congress had been silent on whether jurisdiction would extend to an additional state claim against the same defendant. The way was supposedly left open for assumption of jurisdiction over a pendent state claim. In contrast, the Aldinger Court, citing Monroe v. Pape, ${ }^{40}$ held that Congress had excluded counties from the reach of section 1983 and had thus implicitly stated that counties should not be pendent parties to a section 1983 claim. ${ }^{41}$ The Court restricted its holding to pendent party cases in which the federal claim is brought under sections 1983 and $1343(3)^{42}$ and concluded:

Two observations suffice for the disposition of the type of case before us. If the new party sought to be impleaded is not otherwise subject to federal jurisdiction, there is a more serious obstacle to the exercise of pendent jurisdiction than if parties already before the court are required to litigate a state-law claim. Before it can be concluded that such jurisdiction exists, the federal court must satisfy itself not only that Art. III permits it, but that Congress in the statutes conferring jurisdiction has not expressly or by implication negated its existence. ${ }^{43}$

As will be established below, ${ }^{44}$ the Aldinger Court's second attempt to distinguish Gibbs is also unconvincing.

\section{Pendent Party Jurisdiction}

Aldinger is problematic because pendent party jurisdiction follows logically from Gibbs. Although Gibbs dealt only with a pendent state claim in which the parties were the same as those in the federal claim, the Gibbs test was broader.45 The Gibbs analysis of the "power" of

39. 427 U.S. at 18. See id. at 21-22 (Brennan, J., dissenting).

40. 365 U.S. 167, 187-91 (1961) (legislative history indicates that municipalities may not be sued under $\$ 1983)$.

41. 427 U.S. at 16-17.

42. Id, at 18 .

43. Id.

44. See pp. 646-48 infra.

45. Although the Gibbs Court did not overrule Hurn, it clearly disapproved of Hurn's analysis. 383 U.S. at 725. But Hurn's analysis, when applied to the facts in Gibbs, would have yielded the same jurisdictional result as that reached in Gibbs. Under existing 
federal courts to entertain pendent state claims ${ }^{46}$ looked only to the factual relationship between the state and federal claims, not to the identity of the parties to the claims. If the federal and state claims derived from a common nucleus of operative fact, ${ }^{47}$ then the Gibbs test would grant the power to hear the state claim, irrespective of the identity of the parties to the claims. This view is buttressed by the statement in Gibbs that under the Federal Rules of Civil Procedure, "joinder of claims, parties, and remedies is strongly encouraged." 48

Prior to Aldinger the great majority of lower federal courts had held that the principles in Gibbs permit the exercise of pendent party jurisdiction. ${ }^{49}$ Thus, in Astor-Honor v. Grosset \& Dunlap, Inc., ${ }^{50}$ the Second Circuit upheld the exercise of pendent jurisdiction over a state claim of unfair competition, even though one of the defendants was not a party to the jurisdiction-conferring federal claims. Judge Friendly stated that "[a]lthough the pendent claim in Gibbs did not include a party not named in the federal claim, Mr. Justice Brennan's language and the common sense considerations underlying it seem broad enough to cover that problem also." wi Similarly, before his elevation to the Supreme Court, Justice Blackmun affirmed the extension of federal jurisdiction to a wife's claim for loss of consortium. ${ }^{52}$ The wife's claim was held

precedent, a state claim of unlawful conspiracy to interfere with business relationships could have been held pendent to a federal claim of illegal secondary boycott. United Mine Workers v. Meadow Creek Coal Co., 263 F.2d 52 (6th Cir. 1959) (state and federal claims are different grounds supporting same cause of action-right to be free from wrongful interference with business). In the alternative, the Court could have found that all of the elements of the state claim would have been adjudicated in passing on the federal claim. Shakman, supra note 3, at 264-65. Under pre-Gibbs case law, federal courts were authorized to decide state claims when adjudication of the federal claim would necessarily decide the state claim. $I d$.

46. 383 U.S. at 725 , quoted at p. 630 supra.

47. Id.

48. Id. at 724 (emphasis added).

49. Pendent party jurisdiction has been granted in cases where the plaintiff alleged against employer trustees state claims of breach of fiduciary duty and alleged against union trustees federal claims of violation of Labor-Management Reporting and Disclosure Act $\S 501,29$ U.S.C. $\$ 501$ (1970), and LMRA $\$ \S 301,302,29$ U.S.C. $\$ \$ 185,186$ (1970), e.g., Bowers v. Moreno, 520 F.2d 843 (1st Gir. 1975); accord, Connecticut Gen. Life Assurance Co. v. Craton, 405 F.2d 41 (5th Cir. 1968) (LMRA claim against employer joined with breach of contract claim against insurer), where state claims of unfair competition and federal claims of patent infringement were alleged against various parties who formed a corporation with allegedly purloined trade secrets, Schulman v. Huck Finn Inc., 472 F.2d 864 (8th Cir. 1973), and where a state claim of negligent bailment against a warehouse operator and a federal claim of breach of contract in admiralty against a carrier were alleged, e.g., Leather's Best, Inc. v. S.S. Mormaclynx, 451 F.2d 800 (2d Cir. 1971); accord, Princess Cruises Corp. v. Bayley, Martin \& Fay, 373 F. Supp. 762 (N.D. Cal. 1974).

50. 441 F.2d 627 (2d Cir. 1971).

51. Id. at 629 .

52. Hatridge v. Aetna Cas. \& Sur. Co., 415 F.2d 809 (8th Cir. 1969). 
pendent to her husband's negligence claim against the same defendants:

Although Gibbs concerned claims possessed by a single plaintiff, the decision clearly indicates that "there is power in federal courts to hear the whole." ... Gibbs goes on to say that pendent jurisdiction is a doctrine of discretion and not of the plaintiff's right. "Its justification lies in considerations of judicial economy, convenience and fairness to litigants; if these are not present a federal court should hesitate to exercise jurisdiction over state claims, even though bound to apply state law to them ***. ${ }^{*}$. . These are present here. ${ }^{53}$

Only the Seventh and Ninth Circuits consistently refused to apply Gibbs to pendent party cases. ${ }^{54}$ Significantly, both circuits relied upon pre-Gibbs decisions as authority for their positions. ${ }^{55}$ Gibbs appears to provide, therefore, a clear rationale for pendent party jurisdiction.

Prior to Aldinger the lower federal courts had also applied Gibbs in exercising pendent party jurisdiction where a state claim against a municipality was joined with a section 1983 claim $^{56}$ and where an inference of a congressional intention to exclude a party might have been drawn. Gibbs had served as the basis for extending pendent jurisdiction to cases where federal jurisdiction was premised upon diversity of citizenship rather than a federal question..$^{57}$ In these cases

53. Id. at 816-17 (citations omitted; quoting United Mine Workers v. Gibbs, 383 U.S. $715,725,726(1966))$.

54. Seventh Circuit: Hampton v. City of Chicago, 484 F.2d 602 (7th Cir. 1973), cert. denied, 415 U.S. 917 (1974) (joinder of common law tort claims against city with $\$ 1983$ claim against police denied); Drennan v. City of Lake Forest, 356 F. Supp. 1277 (N.D. Ill. 1972) (same). Ninth Circuit: Moor v. Madigan, 458 F.2d 1217 (9th Cir. 1972), aff'd sub nom. Moor v. County of Alameda, 411 U.S. 693 (1973), discussed in note 8 supra; Hymer v. Chai, 407 F.2d 136 (9th Cir. 1969) (joinder of diversity claim for personal injuries and loss of consortium claim by spouse denied). In Patrum v. City of Greensburg, 419 F.2d 1300 (6th Cir. 1969), cert. denied, 397 U.S. 990 (1970), the Sixth Circuit declined to exercise pendent party jurisdiction where a tort claim against the city was joined with a $\$ 1983$ claim against the policeman. The court relied upon the discretionary criteria of Gibbs and also cited a pre-Gibbs case. Id. at 1302 (citing Wojtas v. City of Niles, 334 F.2d 797 (7th Cir. 1964), cert. denied, 379 U.S. 964 (1965)).

55. Hampton v. City of Chicago, 484 F.2d 602 (7th Cir. 1973) (citing Wojtas v. City of Niles, 334 F.2d 797 (7th Cir. 1964), cert. denied, 379 U.S. 964 (1965)); Hymer v. Chai, 407 F.2d 136 (9th Cir. 1969) (citing Kataoka v. May Dep't Stores Co., 115 F.2d 52I (9th Cir. 1940)).

56. E.g., Glover v. City of New York, 401 F. Supp. 632 (E.D.N.Y. 1975) (\$ 1983 claim against policeman joined with wrongful death claim against city); Eidschun v. Pierce, 335 F. Supp. 603 (S.D. Iowa 1971) (\$ 1983 claim against policeman joined with assault and wrongful death claims against city). See Greenway v. Thompson, 368 F. Supp. 387 (N.D. Ga. 1973) (pendent party jurisdiction may attach to tort claim against city when federal jurisdiction grounded on $\$ 1983$, but Georgia does not recognize actions against municipalities).

57. E.g., F.C. Stiles Contracting Co. v. Home Ins. Co., 431 F.2d 917 (6th Cir. 1970); Jacobson v. Atlantic City Hosp., 392 F.2d 149 (3d Cir. 1968). 
jurisdiction had been extended over pendent claims, even though the amount in controversy was less than the statutory minimum ${ }^{58}$ or complete diversity was defeated. ${ }^{59}$ In addition, pendent jurisdiction had been extended over claims that presented federal questions, but did not allege a sufficient amount in controversy. ${ }^{60}$

The Aldinger Court's analysis would require the dismissal of all of these claims. In each situation, Congress has explicitly or by implication excluded parties or claims not satisfying certain statutory prerequisites. ${ }^{61}$ Yet, by focusing solely on the factual nexus between the state and federal claims, Gibbs implies that all of these claims should be pendent and thus within federal jurisdiction.

The apparent tension between Aldinger and Gibbs suggests that both opinions should be reexamined in light of the fundamental principles underlying the limited jurisdiction of the federal courts. It will be especially important to appraise Aldinger's statutory analysis since that analysis represents the Court's attempt to reconcile Gibbs with the concept of limited jurisdiction.

\section{Gibbs, Aldinger, and Article III}

\section{A. Principles of Limited Federal Jurisdiction}

The Framers placed two restrictions on federal subject matter jurisdiction. First, the language of Article III expressly limits federal jurisdiction to "Cases ... arising under" federal law. ${ }^{62}$ Second, Article III

58. E.g., Beautytuft Inc. v. Factory Ins. Ass'n, 431 F.2d 1122 (6th Cir. 1970); Stone v. Stone, 405 F.2d 94 (4th Cir. 1968), cert. denied, 409 U.S. 1000 (1972).

59. E.g., Wittersheim v. General Transp. Servs., 378 F. Supp. 762 (E.D. Va. 1974); Campbell v. Triangle Corp., 336 F. Supp. 1002 (E.D. Pa. 1972). But see Seyler v. Steuben Motors, 462 F.2d I81 (3d Cir. 1972).

60. Hagans v. Lavine, 415 U.S. 528 (1974); Young v. Harder, 361 F. Supp. 64 (D. Kan. 1973). In Hagans the Court stated:

[T] he rationale of Gibbs centers upon considerations of comity and the desirability of having a reliable and final determination of the state claim by state courts having more familiarity with the controlling principles and the authority to render a final judgment. These considerations favoring state adjudication are wholly irrelevant where the pendent claim is federal but is itself beyond the jurisdiction of the District Court for failure to satisfy the amount in controversy. In such cases, the federal court's rendition of federal law will be at least as sure-footed and lasting as any judgment from the state courts.

415 U.S. at 548 (footnote omitted).

61. 28 U.S.C. $\$ \$ 1331,1332$ (1970 \& West Supp. 1977) (\$10,000 minimum except in actions against United States or its offices or agencies); Strawbridge v. Curtiss, 7 U.S. (3 Cranch.) 267 (1806) (complete diversity required). In Fawvor v. Texaco, 546 F.2d 636 (5th Cir. 1977), the court held that Aldinger required dismissal of a claim that would defeat complete diversity.

62. U.S. CoNST. art. III, $\$ 2$. 
structurally limits federal jurisdiction through the use of the concepts "Court" and "judicial Power." 33

\section{Law-Tied Jurisdiction: "Cases . . arising under" Federal Law}

A desire to preserve existing state court jurisdiction guided the Framers in drafting Article III. Thus, in answer to the charge that the federal courts would usurp state court jurisdiction, Alexander Hamilton stated:

The principles established in a former paper teach us, that the States will retain all pre-existing authorities, which may not be exclusively delegated to the federal head ..... And under this impression, I shall lay it down as a rule that the state courts will retain the jurisdiction they now have, unless it appears to be taken away in one of the enumerated modes. ${ }^{6 t}$

During the ratification debates, defenders of the Constitution similarly insisted that, absent diversity, Article III did not give the federal courts power to hear cases previously cognizable in state courts. ${ }^{65}$

The limitations on federal judicial power are reflected in the tying of the jurisdiction of the federal courts to a body of federal law. ${ }^{66}$ Federal jurisdiction is tied to federal law through the plaintiff's claim and the factual allegations of the pleadings that express the claim. ${ }^{.7}$

63. Id. § 1 .

64. The Federalist No. 82 (A. Hamilton) 553, 553-54 (J. Cooke ed. 1961).

65. At the Virginia Convention George Mason warned that federal jurisdiction would wipe out existing state jurisdiction because of the interrelationship of three constitutional provisions: Congress's ability to create inferior federal courts, U.S. Consr. art. III, $\S I$, the "arising under" clause, id. $\S 2$, cl. 1, and the Supremacy Clause, id. art. VI, cl. 2. 3 J. Eltiot, Debates of the Federal Constitution 521-22 (Washington 1836). Congress could pass laws on virtually every subject regulated by state law and be assured that federal law would be upheld because of the Supremacy Clause. Then, by creating large numbers of federal courts, federal jurisdiction could usurp state jurisdiction because almost all cases would arise under these federal laws. John Marshall answered that "controversies respecting lands claimed under the grants of different states [are] the only controversies between citizens of the same state which the federal judiciary can take cognizance of," id. at 554. A similar exchange occurred at the North Carolina Convention. 4 id. at 136-39, 160.63 (Spencer, making objections similar to Mason's); id. at 139 (Spaight, retorting that federal and state jurisdiction were kept separate); id. at 163 (MacLaine, asserting that except for land grant cases, state jurisdiction unimpaired).

66. Like Gibbs, this Note considers only the limitations on federal question jurisdiction, not those on party jurisdiction. See note 2 supra. An argument might be made that since the federal court is to act as if it were a state court when federal jurisdiction is grounded on diversity, Erie R.R. Co. v. Tompkins, 304 U.S. 64 (1938), the federal court should have the jurisdictional powers of a state court. But see pp. 648-50 infra.

67. Skelly Oil Co. v. Phillips Petroleum Co., 339 U.S. 667 (1950); Fed. R. Civ. P. 8(a); see P. Bator, P. Mishien, D. Shapiro \& H. Wechsler, Hart \& Wechsler's The FEDERAl Courts AND The Federal System 835-36 (2d ed. 1973) thereinafter cited as HarT \&: WECHSLER]; F. JAMES \&: G. HAZARD, supra note 26, at 58. 
These allegations assert the violation of legal rights. ${ }^{68}$ But a group of operative facts may give rise to more than one violation of legal right, ${ }^{60}$ whose source may be in either state or federal law. A federal court has jurisdiction over a claim only if the right allegedly violated has its source in federal law ${ }^{70}$ and Congress has conferred jurisdiction over that right on the federal courts. ${ }^{71}$ By tying federal jurisdiction to a body of federal law and thereby divorcing that jurisdiction from state

68. C. Clark, supra note 26, at 146-48; F. JAMEs \& G. HAZARD, supra note 26, at 75-76. 69. C. ClarK, supra note 26, at 137; F. JAMEs \&. G. HAzARD, supra note 26, at 553. 70. U.S. Const. art. III, $\S 2$ (judicial power shall extend to all cases "arising under this Constitution, the Laws of the United States, and Treaties made . . . under their Authority"); 28 U.S.C.A. $\$ 1331$ (a) (West Supp. 1977) ("The district courts shall have original jurisdiction of all civil actions wherein the matter in controversy exceeds the sum or value of $\$ 10,000$, exclusive of interest or costs, and arises under the Constitution, laws, or treaties of the United States except that no such sum or value shall be required in any such action brought against the United States, any agency thereof, or any officer or employee thereof in his official capacity.") The words "arising under [federal law]" imply that federal law defines the cases cognizable in federal courts. In other words, the violation of a federally protected legal right establishes the jurisdiction of the federal courts.

For judicial constructions of the "arising under" clause that support this "source of law" interpretation, see International Ass'n of Machinists v. Central Airlines, Inc., 372 U.S. 682, 696 (1963) (suit to enforce award of airline board of adjustment, created by contract pursuant to Railway Labor Act, 45 U.S.C. $\$ \S 151,184$ (1970), arises under federal law because it has its source in Act); American Well Works Co. v. Lane \& Bowler Co., 241 U.S. 257 (1916) (suit for injury to business caused by threat to sue for patent infringement not in itself suit arising under federal law); The Fair v. Kohler Die Co., 228 U.S. 22 (1913) (action alleging patent infringement arises under patent laws and is within federal jurisdiction). This clause has also been interpreted as permitting federal jurisdiction: (I) if the right to relief depends upon a construction or application of federal law, Smith v. Kansas City Title \& Trust Co., 255 U.S. 180, 201 (1921) (shareholder action to enjoin directors from placing funds in Federal Land Banks arises under federal law because suit alleges that Act creating Banks is unconstitutional); Shulthis v. McDougal, 225 U.S. 561, 569 (1912) (case does not arise under federal law unless it substantially involves dispute respecting construction, validity, or effect of such law); or (2) if federal law is an essential element of the right to relief, Gully v. First Nat'l Bank, 299 U.S. 109, 115 (1936) (action to collect state taxes from successor of nationally chartered bank does not arise under federal law because charter is not essential element). Although this Note's interpretation of "arising under" may be difficult to reconcile with the other two interpretations, all three views require at minimum that federal law be crucial to the vindication of the right asserted in the claim. See HART \& WECHSLER, supra note 67, at 883-90. Put another way, even if state law is the source of the right asserted, a case must directly rely upon federal law before it is within federal jurisdiction. ALI, supra note 3, at 178-79; Cohen, The Broken Compass: The Requirement that a Case Arise "Directly" under Federal Law, 115 U. PA. L. REv. 890, 896 (1967); Mishkin, The Federal Question in the District Courts, 53 Colum. L. REv. 157, 165-66, 168 (1953). Since federal law may be crucial to some state claims or may be directly relied upon in those claims, the importance of maintaining the integrity and supremacy of federal law may justify a departure from a literal devotion to the "source of law" analysis.

71. Ex parte McCardle, 74 U.S. (7 Wall.) 506, 514 (1869) ("the power to make exceptions to the appellate jurisdiction of this court is given by express words"); Sheldon v. Sill, 49 U.S. (8 How.) 444, 449 (1850) ("having the right to prescribe, Congress may withhold from any court of its creation jurisdiction of any of the enumerated controversies"); see U.S. Const. art. III, § 1, § 2 cls. $1,2$. 
law, this "source of law" examination preserves a system of limited jurisdiction. ${ }^{2}$

\section{Implied Jurisdictional Power: "Judicial Power" and "Courts"}

It may be possible to infer jurisdictional power over state claims from the Framers' use of certain concepts in Article III. Thus the extension of "judicial Power" to "Courts" may imply that unless the federal courts have power to hear some state claims, the federal courts will neither function as "Courts" nor exercise "judicial Power."73 This argument is not new. It is the foundation of the long-recognized and much-discussed doctrine of ancillary jurisdiction. ${ }^{74}$ An examination of ancillary jurisdiction, however, shows that, correctly formulated; it exhausts the jurisdictional power that may be inferred from the "Court" and "judicial Power" concepts.

Ancillary jurisdiction originally allowed federal courts to consider matters not normally within their express jurisdiction in order to give effect to their jurisdictional mandate. ${ }^{75}$ Thus, in Freeman $v$. Howe $e^{76}$ the federal court had attached the defendant's railroad cars. The Supreme Court upheld the federal attachment and struck down an attachment pursuant to a subsequent state court suit by the defendant's mortgagees. The mortgagees contended that they must be allowed to prosecute their state suit because they were not of diverse citizenship

72. An analogy is afforded by the system of limited jurisdiction in Australia. The Australian Constitution confers jurisdiction on the High Court in part as follows:

The Parliament may make laws conferring original jurisdiction on the High Court in any matter-

(i) Arising under this Constitution, or involving its interpretation:

(ii) Arising under any laws made by Parliament.

AustL. CoNST. $\S 76$. Section 77 of the Australian Constitution authorizes Parliament to make laws defining the jurisdiction of lower federal courts with respect to matters delineated in $\$ 76$. Section 76 has been construed as follows:

[I]n order to bring a matter within s. 76(ii) ... the inquiry to be made is not whether the determination of the matter involves the interpretation of a Federal law. The relevant inquiry is whether the matter arises under the law. Thus one is compelled to the conclusion that a matter may properly be said to arise under a Federal law if the right or duty in question in the matter owes its existence to Federal law or depends on Federal law for its enforcement, whether or not the determination of the controversy involves the interpretation (or validity) of the law. The King v. Commonwealth Ct. of Conciliation \& Arbitration, 70 C.L.R. 141, 154 (Austl. 1945). The High Court subsequently affirmed this view in Collins v. Charles Marshall Proprietary Ltd., 92 C.L.R. 529, 540 (Austl. 1955). An Australian claim must assert the violation of a federal right to come within federal jurisdiction; Australian federal jurisdiction is thus defined by federal law. The drafters of the judicature chapter of the Australian Constitution were strongly influenced by the American Constitution. $Z$. Cowen, Federal Jurisdiction in Australia ix-xv (1959).

73. ALI, supra note 3, at 207-08.

74. Id.

75. 13 WRIGHT \& MLLER, supra note $3, \S 3523$.

76. 65 U.S. (24 How.) 450 (1860). 
and thus could not join the federal court proceeding. ${ }^{77}$ The Court rejected this contention and stated that the mortgagees were entitled to have their claims heard in the federal suit in order to prevent a conflict between the state and federal courts. ${ }^{78}$

After Freeman, ancillary jurisdiction was allowed over two classes of matters: proceedings that threatened the judgments, decrees, or processes of the federal courts, and proceedings respecting property within the control of federal courts. ${ }^{79}$ Ancillary jurisdiction, therefore, was at first primarily a doctrine that vindicated federal authority. It permitted extension of federal jurisdiction only to prevent frustration of the expressly defined jurisdictional powers of federal courts. Judicial economy and fairness to the litigants were secondary, if salutary, results of the doctrine.

This original conception of ancillary jurisdiction exhausts the jurisdictional powers that may be implied by the "Court" and "judicial Power" concepts. Since a law-tied jurisdictional test is the foundation for federal subject-matter jurisdiction, ${ }^{80}$ the only construction of "Court" and "judicial Power" consistent with this express jurisdictional scheme is one that would permit those concepts to reach beyond federal law to the extent necessary to protect law-tied jurisdiction itself. ${ }^{81}$ Such

77. Id. at 460 .

78. Id. at $457-58,460$.

79. Judgments, decrees, and processes: e.g., Supreme Tribe of Ben-Hur v. Cauble, 255 U.S. 356 (1921) (state court action challenging insurance society reorganization by nondiverse policyholders enjoined); Cooperative Transit Co. v. West Penn Elec. Co., 132 F.2d 720 (4th Cir. 1943), cert. denied, 318 U.S. 779 (1943) (claim for property under after-acquired property clause in mortgage not within ancillary jurisdiction because new parties introduced, property not before court in prior action, and issues new). Property: e.g., White v. Ewing, 159 U.S. 36 (1895) (receiver may sue on company's notes despite lack of diversity or insufficient amount in controversy since federal court controls company's assets); Krippendorf v. Hyde, 110 U.S. 276 (1883) (nondiverse party may sue when federal court attaches goods in his possession). Shakman, supra note 3, at 270.77 , bases his criticism of the reasoning in Gibbs largely on these limitations on ancillary jurisdiction.

80. See pp. 637-39 supra.

81. By its very nature, an argument for implied powers seeks powers necessary to protect or effect expressly defined powers. The Supreme Court recognized this limitation as early as 1812 in United States $v$. Hudson \& Goodwin, when it rejected the notion that the federal courts possess a common law criminal jurisdiction:

When a Court is created, and its operations confined to certain specific objects, with what propriety can it assume to itself a jurisdiction much more extended?

....

.. Certain implied powers must necessarily result to our Courts of Justice from the nature of their institution. But jurisdiction of crimes against the state is not among those powers. To fine for contempt-imprison for contumacy-inforce the observance of order, $-\&$. . are powers which cannot be dispensed within a court, because they are necessary to the exercise of all others: and so far, our Courts no doubt possess powers not immediately derived from statute; but all exercise of criminal jurisdiction in common law cases we are of the opinion is not within their implied powers.

11 U.S. (7 Cranch) $32,33-34$ (1812). 
an exercise of jurisdiction would be available only to protect the judgments and processes of the federal courts and property in their control; the exercise would thus be identical to the original conception of ancillary jurisdiction.

\section{B. Application to Gibbs and Aldinger}

In light of the jurisdictional scheme established by Article III, Gibbs provides for an unconstitutionally over-expansive test for pendent jurisdiction. The principal failures of the Gibbs test are, first, that it is fact-tied rather than law-tied and, second, that it ignores Congress's primary power to control federal jurisdiction. Moreover, the Gibbs doctrine cannot be saved from these objections by arguing that ancillary jurisdiction supports pendent jurisdiction. Finally, the historical evidence tends to show that the Court's construction of "case" itself is incorrect.

In the "power" step of its analysis," 82 Gibbs focused solely on the facts alleged in the claim..$^{83}$ If there is a common nucleus of operative fact, the federal courts have the power to exercise jurisdiction. ${ }^{84}$ The Framers, however, provided for a law-tied system of jurisdiction that excluded state claims from the federal courts, absent diversity of citizenship. ${ }^{85}$ Since a group of operative facts may give rise to several violations of legal rights, ${ }^{80}$ a fact-tied jurisdictional test may permit federal courts to adjudicate legal rights whose origins are outside federal law. ${ }^{87}$ The fact-tied Gibbs test thus permits federal intrusion

82. See p. 630 supra.

83. This Note addresses only the constitutionality of the "power" step in Gibbs. The Gibbs Court intended that its test mark the constitutional boundaries of jurisdictional power, but permitted the district courts to abjure the exercise of jurisdiction for discretionary reasons. 383 U.S. at 726. It is appropriate to limit this analysis to the "power" step. If the "power" step is valid, exercise of discretion will remain within constitutional boundaries. If the "power" step is overly expansive, however, observance of the jurisdictional limits of Article III would then depend upon the discretion of federal trial judges. This undesirable result can be avoided by a clear formulation of criteria to guide the exercise of jurisdictional power. See pp. 648-50 infra.

84. 383 U.S. at 725 .

85. See pp. 637-39 \& notes 64-72 supra.

86. See note 69 supra.

87. E.g., Mobil Oil Corp. v. Kelley, 493 F.2d 784 (5th Cir.), cert. denied, 419 U.S. 1022 (1974) (action to force state to issue previously approved drilling permits where oil company alleged Fourteenth Amendment taking claim and unjust enrichment theory); McCurnin v. Kohlmeyer, 477 F.2d 113 (5th Cir. 1973) (action against broker for disobeying purchase instructions where federal claim of willful misrepresentation under Commodities Exchange Act, 7 U.S.C. $\$ 6(\mathrm{~b})$ (1970), dismissed, but recovery on state law of agency permitted); Knuth v. Erie-Crawford Coop. Ass'n, 395 F.2d 420, 426-27 (3d Cir. 1968), cert. denied, 410 U.S. 913 (1973) (state claims of fraudulent conversion of plaintiff's money, tortious interference with plaintiff's advantageous business relations, and violations of Pennsylvania Milk Control Act held pendent to federal claims of violations 
into state law in contravention of the Framers' jurisdictional scheme. By basing its conception of pendent jurisdiction on the term "case" in Article III, the Gibbs Court also failed to recognize the requirement of a congressional conferral of jurisdiction. ${ }^{88}$ Such recognition would be unnecessary only if "case" in Article III and the conferrals of jurisdiction in section 1331 and other jurisdictional statutes are regarded as coextensive. ${ }^{89}$ And if the Court did equate the scope of "case" and congressional conferrals of jurisdiction, it ignored precedent to the contrary: section 1331 and other jurisdictional statutes do not exhaust the limits of federal jurisdiction established by Article III..$^{90}$ Further, in construing section 1331, which most closely approximates the language of Article III, the courts have used the "source of law" analysis discussed above, not a test based upon fact-relatedness. ${ }^{\mathbf{} 1}$

The federal courts' implied jurisdictional power, or ancillary jurisdiction, cannot justify the broad pendent jurisdiction declared in Gibbs. ${ }^{92}$ Ancillary jurisdiction, in its original and most precise sense, meant something quite different from pendent jurisdiction: it ex-

of Sherman Act $\$ \S 1,2,15$ U.S.C. $\$ \S 1,2$ (1970)). Shakman, supra note 3, at 265, also noted the potential intrusiveness of Gibbs. His reasons for criticizing this intrusiveness -encouraging the development of state court expertise in deciding federal questions, $i d$. at. 266, and the likelihood that federal courts will err as much as state courts in deciding nonjurisdictional claims, $i d$. at 267-78-seem highly speculative. In addition, Shakman failed to recognize the distinction between a law-tied and fact-tied jurisdictional test and the importance of the distinction to pendent jurisdiction.

88. See p. 638 supra.

89. The Gibbs test for pendent jurisdiction was stated in the context of a general statement on the history and scope of the doctrine. 383 U.S. at 721-27. The opinion thus goes beyond the particular jurisdictional situation before it. See also note 45 supra. The actual jurisdictional statute before the court, however, was clearly a law-tied grant. LMRA \$ 303(b), 29 U.S.C. \$ 187(b) (1970), states that "[w]hoever shall be injured in his business or property by reason or [sic] any [unfair labor practice] may sue therefor in any district court of the United States ....." "Unfair labor practice" is defined in 29 U.S.C. $\$ 158(b)(4)(1970)$. In reaching its decision, the Court ignored the congressional conferral of jurisdiction that was present in Gibbs and only discussed the constitutional parameters of "case." The Court's failure to recognize the need for a congressional conferral of jurisdiction is justified only if it regarded "case" and the suits authorized by 29 U.S.C. $\$ 187$ (b) $(1970)$ as coextensive. But even if the Court were tracking the Article III "case" with the suits authorized by 29 U.S.C. $\$ 187$ (b) (1970), that statutory provision, like $\$ 1331$, provides for jurisdiction over actions to vindicate rights whose source is in federal law. Hence the Court's fact-tied conception of case is inconsistent with Congress's jurisdiction-conferring statute in Gibbs, 29 U.S.C. $\$ 187(b)(1970)$.

90. Article III and $\S 1331$ seem textually coextensive. The sparse legislative history indicates that the statutory grant was intended to exhaust the Constitutional grant of jurisdiction. HART \& WechsLer, supra note 67 , at 871 . Yet $\$ 1331$ has not been regarded as synonymous with Article III. C. Wright, The Law of Federal CourTs 64-66 (1976). First, the requirement in $\S 1331$ that a minimum amount in controversy be satisfied is not found in Article III. Second, federal jurisdiction may be defeated under $\$ 1331$, but not under Article III, if a federal question arises only by way of defense. Compare Osborn v. Bank of United States, 22 U.S. (9 Wheat.) 738 (1824) with Louisville \& N.R.R. v. Mottley, 211 U.S. 149 (1908).

91. See note 70 supra.

92. ALI, supra note 3, at 207-08. 
panded express federal jurisdiction when it was necessary to protect the federal courts' jurisdictional mandate. ${ }^{93}$ Since Gibbs justifies exercise of pendent jurisdiction on grounds other than necessity-judicial economy and fairness to the litigants-ancillary jurisdiction provides no support for the broad test in Gibbs. ${ }^{94}$ In the last fifty years, ancillary jurisdiction has departed from this original conception. Its policies and the test for its application have blurred with those of pendent jurisdiction so that ancillary jurisdiction, in this more contemporary and less precise sense, has become virtually synonymous with broad pendent jurisdiction. ${ }^{05}$ To the extent that ancillary and pendent jurisdiction are now coextensive, any attempt to justify the latter by reference to the former is circular.

In addition, it is not clear that the Gibbs Court's interpretation of "case" in Article III is within constitutional boundaries. ${ }^{90}$ The Gibbs opinion omitted virtually any discussion of the Framers' intent in using "case" in Article III. ${ }^{97}$ Although the historical evidence is limited

93. See pp. 639-41 supra.

94. Just as the state claim actually before the Court in Gibbs might have been held pendent under existing case law, see note 45 infra, adjudication of the state claim may have also been permitted under the "necessity" conception of ancillary jurisdiction. The existence of the state claim raised the possibility of inconsistent verdicts and a conflict between state and federal courts.

95. Moore v. New York Cotton Exch., 270 U.S. 593, 609 (1926) (federal court has ancillary jurisdiction to hear nonfederal counterclaim because it arises out of same factual transaction as federal claim); United States v. United Pac. Ins. Co., 472 F.2d 792, 794 (9th Cir.), cert. denied, 411 U.S. 982 (1973) ("Ancillary jurisdiction promotes the economical and expeditious administration of justice by avoiding a multiplicity of suits through permitting issues and claims arising out of the same operative facts to be embraced in a single action."); Comment, supra note 3, at 1265-71.

Although there is a substantial conflict in the case law on the scope of ancillary jurisdiction, 13 WRIGHT \& MILLER, supra note $3, \S 3523$, at 66 , a consensus probably permits its exercise over compulsory counterclaims, cross-claims, impleader of third-party defendants, interpleader, and intervention as of right. Permissive counterclaims and permissive intervention are generally not permitted. Id. at 66-70. Under the Freeman view, see pp. 639-40 supra, ancillary jurisdiction would probably only extend to impleader, interpleader, and intervention as of right, and then only to the extent that jurisdiction is necessary to vindicate federal authority. The other situations in which ancillary jurisdiction has been exercised should be tested according to the standard proposed at pp. 64850 infra. The relationship between ancillary and exclusive jurisdiction is discussed further in note 115 infra.

96. Constitutional terms may be construed by examining their meaning during the period in which the Constitution was framed. See Hurst, The Process of Constitutional Construction, in Supreme Court and Supreme Law 57 (E. Cahn ed. 1954) ("jury" and "legislature"). Alternatively, these terms may be taken as general guides that later generations define according to their own values. See id. at 61 (remarks by Professor Freund in panel discussion) ("due process"). As the discussion in notes 98 and 99 infra indicates, it is possible to lend some meaning to "case" through the first mode of analysis.

97. The Court did refer to Article III when it noted that " $[t]$ he question whether joined state and federal claims constitute one 'case' for jurisdictional purposes is to be distinguished from the often equally difficult inquiry whether any 'case' at all is presented." 383 U.S. at 725 n.25. But this statement is irrelevant to the scope of "case" in Article III. 
and often ambiguous, there are a number of indications that the term refers to the traditional judicial business of the English courts. ${ }^{98}$ An examination of the meaning of "case" at the time the Constitution was adopted tends to show that "case" was defined in terms of the right asserted, not in terms of a factual unit.99

98. See Hayburn's Case, 2 U.S. (2 Dall.) 409, 413-14 (1792). In Hayburn's Case, Attorney General Edmund Randolph sought a writ of mandamus ex officio to compel a circuit court to proceed upon a veteran's petition for a pension. His motion was denied. Randolph's failure to satisfy the "case or controversy" requirement of Article III by showing sufficient adversity of legal interests led him to inquire of the Court the practice it would follow. The Court responded that "[t]he Court considers the practice of the courts of King's Bench and Chancery in England, as affording the outlines for the practice of this court; and that they will, from time to time, make such alterations therein, as circumstances may render necessary." Id. at 413-14. The Court's statement is not without ambiguity. The most reasonable interpretation is that the Court accepted common law practice as an outline, but that it reserved the right to alter the details within this outline. The Court's statement may also mean that it wanted the flexibility to alter completely the procedural content of "case." Five Framers-William Paterson, James Wilson, John Rutledge, John Blair, and Oliver Ellsworth-were present on the Court at the time.

Subsequent judicial constructions of "case" have also looked to the traditional judicial business of the English courts at the time the Constitution was framed and adopted. Joint Anti-Fascist Refugee Comm. v. McGrath, 341 U.S. 123, 150 (1951) (standing); Muskrat v. United States, 219 U.S. 346, 355 (1910) (advisory opinions); California v. Southern Pac. Co., 157 U.S. 229, 248-5I (1895) (indispensability of parties).

Only one attempt at definition of "case" occurred during the Constitutional Convention. As the jurisdictional clauses of Article III were being clarified, it was moved that jurisdiction be extended to cases arising under the Constitution as well as the laws of the United States. Madison asked whether jurisdiction should be limited to cases of a "Judiciary Nature." But the motion was adopted, "it being generally supposed that the jurisdiction given was constructively limited to cases of a Judiciary nature." 2 M. Farrand, The Records of The Federal Convention of 1787, at 430 (1911). In light of this exchange, Madison's later statements may thus show that "case" is to be defined according to the usages of the English common law at the time the Constitution was adopted. 9 The Writings of James Madison 198 (G. Hunt ed. 1910) (in 1824 letter, noting that limited nature of federal government precludes incorporation of common law into Constitution, but agreeing that Constitution "borrows from the common law terms which must be explained by [common law] authorities").

99. Chief Justice Marshall stated in Cohens v. Virginia, 19 U.S. (6 Wheat.) 264 (1821), that Article III "does not extend the judicial power to every violation of the constitution which may possibly take place, but to 'a case in law or equity,' in which a right, under such law, is asserted in a Court of justice." $I d$. at 405 . Later in the same opinion the Chief Justice again asked:

What is a suit? We understand it to be the prosecution, or pursuit, of some claim, demand, or request. In law language, it is the prosecution of some demand in a Court of justice. The remedy for every species of wrong is, says Judge Blackstone, "the being put in possession of that right whereof the party injured is deprived." "The instruments whereby this remedy is obtained, are a diversity of suits and actions, which are defined by the Mirror to be "the lawful demand of one's right.'["] ... Blackstone then proceeds to describe every species of remedy by suit; and they are all cases [where] the party suing claims to obtain something to which he has a right.

Id. at 407-08 (quoting $3 \mathrm{~W}$. Blackstone, Commentaries *116). Authors of legal dictionaries of the eighteenth century also regarded suits-forms of action and bills in equity-as the means of vindicating a right. 1 CUNningham's LAW DictioNaRY (1764) ("action"; "bill"); JacoB's LAW DictionaRY (I773) ("action"; "bill"). An early nineteenth century treatise writer agreed. 1 J. Chitry, Pleading 84-87 (New York 1809). These authorities regarded 
The Gibbs Court thus did little more than assume the conclusion in declaring a fact-based standard of pendent jurisdiction. The only authority the Court cited for its constitutional interpretation was the Federal Rules of Civil Procedure, which allow joinder of claims arising from the same factual transaction. ${ }^{100}$ The Rules also state, however, that they should not be construed as extending federal jurisdiction. ${ }^{101}$ In a footnote, the Court dismissed this qualification as a "commonplace," asserted that the Rules "embody the whole tendency of our decisions," and cited for that proposition Baltimore Steamship Co. $v$.

"case" as the action of trespass on the case. But "case" could not be indiscriminately joined with actions arising from the same facts. Different counts could be joined in the same action if they were of the same "nature," $i d$. at 195-97, or were variations of the same species of wrong, Tind's Practice 10-11 (9th ed. 1828).

Although these authorities defined the bill in equity in terms of a right, the scope of equity proceedings might have been broader. The drafters of the Field Code, New York, First Report of the Commissioners, $\$ 120(2)$ (1848), out of which the transactional definition grew, looked to the traditional discretion and flexibility of the chancellor for their model. F. JAMES \& G. HAZARD, supra note 26, at 12-15, 66. In practice, equity allowed the decision of issues at law and the liberal joinder of claims, subject to a vaguely defined objection against multifarious suits. Id. at 457 .

The expansion of equity was opposed by the Framers, because equity was believed to represent the royal prerogative. For this reason and others, there was a strong antichancellor movement in colonial America. L. Friedman, A History of American Law 47-51, 130-31 (1973); Waterman, Thomas Jefferson and Blackstone's Commentaries, in Essays in the History of EARLy AMerican LAw 451, $469-70$ (D. Flaherty ed. 1969). Reading the reference to equity in Article III as permitting a broad definition of "case" is, therefore, an uncertain enterprise.

That the Framers shared an understanding of "case" as the procedural vehicle for adjudicating an alleged violation of a legal right is also indicated by the statements made during the Ratification Debates. See p. 637 \& note 65 supra. The Framers' insistence that existing state jurisdiction would be preserved is inconsistent with a transactional definition of "case." A transactional definition would allow adjudication of claims falling solely under state court jurisdiction by the federal courts by virtue of the factual connection of those claims to the federal claim. Moreover, since opponents of the Constitution attacked its supposed failure to restrain federal power, J. MAIN, THE ANTIFEDERALISTs 120 (1961), any interpretation of "case" that would have permitted the federal judiciary wide jurisdictional powers would doubtless have drawn sharp criticism. Yet, the records of the ratification debates are barren of such criticism.

The narrowing of language used to describe federal jurisdiction in the Constitutional Convention also points to this conclusion. In the first draft of the Committee of Detail, jurisdiction was extended to "all cases of national revenue, impeachment of national officers, and questions which involve the national peace or harmony." 1 M. FARRAND, supra note 98 , at 238 . This language would have allowed room for a transactional definition since a state claim growing out of the same factual transaction with a federal claim might be said to "involve" the national peace or harmony. Further, the language refers to questions rather than cases. The description of jurisdiction, however, was later rephrased to its present form.

Probably the most compelling reason for regarding "case" as the violation of a legal right is that the Framers would have been aware only of that definition. The transactional definition did not make its appearance until the Field Code of 1848. C. Crark, supra note 26, at 22; F. JAMEs \& G. HAZARD, supra note 26, at 19.

100. 383 U.S. at $724 \&$ n.10 (citing, inter alia, FEv. R. CIv. P. 18-20).

10I. Fed. R. Giv. P. 82. 
Phillips, ${ }^{102}$ a case that advanced the definition of the cause of action that the Gibbs Court explicitly rejected. ${ }^{103}$

In constrast, the propositions that the Aldinger Court urged as support for restricting pendent party jurisdiction have general validity. The federal courts are indeed courts of limited jurisdiction. ${ }^{104}$ And the scope of pendent jurisdiction should be determined by examining the "scope of the cause of action as to which federal judicial power has been extended by Congress."105 But the Aldinger opinion failed to discern the full implications of its statutory analysis. Once these implications are realized, Aldinger is inconsistent with Gibbs.

Justice Brennan's dissent in Aldinger suggests the implications of the Court's reasoning. He attacked the notion that pendent party jurisdiction should be denied if Congress by implication has refused to allow subject-matter jurisdiction over a party:

At one level of analysis, this test is of course meaningless, being capable of application to all cases, because all instances of asserted pendent-party jurisdiction will by definition involve a party as to whom Congress has impliedly "addressed itself" by not expressly conferring subject-matter jurisdiction on the federal courts. ${ }^{100}$

Justice Brennan was concerned that the majority's test meant that congressional silence would suffice to imply disapproval of pendent party jurisdiction; all pendent party jurisdiction would thus be negated. The Justice observed, therefore, that the Court's test would have to require something more than mere silence as an expression of congressional disapproval. He then went on to examine the legislative history of sections 1983 and 1343(3) and concluded that Congress had not necessarily negated pendent jurisdiction over the state claim in Aldinger. ${ }^{107}$

Yet a distinction between congressional silence and explicit or implicit congressional disapproval is itself meaningless. Congressional silence may have a variety of meanings. It may mean that Congress has not considered whether jurisdiction should be extended over a matter or party and thus has no opinion on the subject. It should be

102. 383 U.S. at 725 n.13 (citing Baltimore S.S. Co. v. Phillips, 274 U.S. 316 (1927)). In also criticizing the threadbare support that the Court relied upon, Shakman, supra note 3, at 268-70, neglected to discuss the effect of FED. R. CIv. P. 82 in undercutting the Court's rationale.

103. 274 U.S. at 321.

104. See note 38 supra.

105. 427 U.S. at 17 (emphasis in original); see pp. 637-38 supra.

106. 427 U.S. at 23 (emphasis in original).

107. Id. at 23-30. 
remembered in this regard that Congress has yet to grant the full constitutional measure of jurisdiction. ${ }^{108}$ Congressional silence may also mean that Congress believes that it has already passed statutes conferring jurisdiction over the matter or party. ${ }^{109}$ Finally, congressional silence may mean that extension of jurisdiction is so disfavored in Congress that the question has never been seriously raised.110 Congressional silence, therefore, is ambiguous; it cannot be interpreted until there is some subsequent congressional action dealing with the subject.

Moreover, under the principles of limited jurisdiction, Article III conditions the exercise of federal jurisdiction on the existence or passage of some federal law and a congressional conferral of jurisdiction over that law. ${ }^{111}$ Ambiguous congressional silence respecting a matter or party is thus as fatal to the exercise of federal jurisdiction as some form of "active" congressional disapproval.112 The untenability of the distinction between "active" congressional disapproval and "passive" congressional silence follows from the "source of law" anal-

108. See note 90 supra.

109. An example might be found in Congress's continuing refusal expressly to confer jurisdiction over municipalitics under $\$ 1983$. Congress may believe that $\$ 1331$ already permits suits to be brought against municipalities for civil rights violations through direct reliance on the Fourteenth Amendment. The Aldinger Court noted the argument for such suits but did not reach that question. 427 U.S. at 4 n.3.

110. The Pacific Railroad Removal Cases, 115 U.S. I (1885), offer a possible example. The Supreme Court's decision that the railroads' federal charter of incorporation was sufficient for jurisdiction under the predecessor of $\$ 1331$, The Judiciary Act of 1875 , ch. $137, \$ 1,18$ Stat. 470 , widencd the general federal question jurisdiction granted by Congress. F. Frankfurter \& J. Landis, The Business of the Supreme Court 69 (1927). Heeding the pleas of a contrite Court, id. at 272-74, Congress prohibited such a basis for federal jurisdiction with respect to railroads, Act of Jan. 28,1915 , ch. $22, \S 5,38$ Stat. 804, and later with respect to all corporations, Act of Feb. 13, 1925, ch. 229, $\$ 12,43$ Stat. 941 (present version at 28 U.S.C. $\$ 1349(1970)$ ).

111. See p. 638 supra.

112. Justice Brennan's dissent indicates the difficulties inherent in discerning implicit congressional approval or disapproval of the exercise of federal jurisdiction. The legislative history of $\S 1983$ does not clearly support the majority's findings of an explicit or implied rejection of jurisdiction over municipalities. 427 U.S. at 23-30. Congress may well have approved of federal jurisdiction over state-created actions against municipalities under the diversity head. Id. at 25 . The jurisdiction that Congress rejected was cognizance of federally created actions against municipalities. Id. at 24-25. In addition, it makes little sense to speak of congressional intent of any sort to exclude municipalities from being pendent parties since pendent jurisdiction was unheard of until Hurn $v$. Oursler, 289 U.S. 238 (1933).

Reiser v. District of Columbia, No. 76-1411 (D.C. Cir. Aug. 15, 1977), is an example of the judicial confusion that results from the Aldinger standard. In Reiser a claim against the District of Columbia was joined with a diversity claim against an individual. Although the court acknowledged that states are not citizens of themselves and thus cannot be sued under $\$ 1332$, and that $\$ 1332$ seems to regard the District as a "state," it upheld pendent party jurisdiction in the face of Aldinger, remarking that "the very existence of pendent jurisdiction depends upon the conclusion that the federal court has no direct jurisdiction over the case." Id. at 19. 
ysis and the constitutional allocation to Congress of the power to control federal jurisdiction. ${ }^{113}$ The conclusion that Justice Brennan feared is thus correct: all pendent party jurisdiction is improper under Aldinger.

The statutory analysis of Aldinger may be taken to its logical conclusion by noting that every purely state law claim involves by definition substantive law that Congress cannot enact or has failed to enact. Since Aldinger requires the federal courts to determine the reach of their jurisdiction by construing the scope of the cause of action to which the judicial power has been extended by Congress, Congress's failure to create the state-defined cause of action should negate jurisdiction over the state claim. The Gibbs version of pendent jurisdiction thus would be completely destroyed.

The Aldinger Court undertook an analysis fundamentally different from that of the Gibbs Court. The Gibbs Court looked only to the supposed scope of "case" in Article III in determining the extent of pendent jurisdiction. Understandably nervous at the prospect of circumventing what is regarded as a congressional intention to exclude a party from federal jurisdiction, the Aldinger Court has rediscovered the necessity of congressional action to the establishment of federal jurisdiction.

\section{Constitutional Pendent Jurisdiction}

A constitutional test for pendent jurisdiction would require the federal court to examine the rights asserted in the plaintiff's claims. Under this test, the federal court may take jurisdiction over claims that assert both state and federal rights, but only if the state and federal rights are substantially identical.114 Rather than require a common nucleus of operative fact, the federal courts would require a "common nucleus of operative law." 115 In comparing the state and federal rights,

113. See p. 638 supra.

114. Hurn v. Oursler, 289 U.S. 238 (1933), see pp. 629-30 supra, was therefore correct in focusing upon rights rather than facts. The case may have failed as a standard for pendent jurisdiction because of its lack of clarity in drawing the distinction between a "ground" and a "cause of action." 289 U.S. at 246. Additionally, in stating that "the claims of infringement and unfair competition so precisely rest upon identical facts as to be little more than the equivalent of different epithets to characterize the same group of circumstances," id., the Court seemed to emphasize the close factual relationship of the claims. See Armstrong Paint \& Varnish Works v. Nu-Enamel Corp., 305 U.S. 315, 325 (1938). Nevertheless, the Hurn Court later quoted Baltimore S.S. Co. v. Phillips, 274 U.S. 316 (1927), to the effect that " "[a] cause of action does not consist of facts, but of the unlawful violation of a right which the facts show." 289 U.S. at 246 (quoting 274 U.S. at 321). The debate over the meaning of "cause of action," see p. 631 supra, may have contributed to the confusion.

115. The Court in Gibbs justified broad pendent jurisdiction partly on the basis of 
the federal court would employ the familiar tools of the judicial process-logic, precedent, statutory history, and adaptation of existing rules of law to changing mores and social patterns. Congressionally

"considerations of judicial economy." 383 U.S. at 726. The validity of the judicial economy argument depends in large part upon the system in which the supposed economies will occur. From the point of view of the federal system, broad pendent jurisdiction cannot result in judicial economy since state matters not otherwise cognizable will be adjudicated. Restrictive pendent jurisdiction actually better furthers the goal of judicial economy in the federal courts. If the federal and state courts are viewed as part of a unitary system, then broad pendent jurisdiction may result in judicial economy because litigants may bring all their claims in one forum-the federal court. But restrictive pendent jurisdiction also permits this result since litigants can generally bring both federal and state claims in one forum-the state court. Charles Dowd Box Co. v. Courtney, 368 U.S. 502, 507-08 (1962); Claflin v. Houseman, 93 U.S. 130, 134 (1876) (decided under Bankruptcy Act of 1867, ch. 176, 14 Stat. 517, providing for concurrent state and federal jurisdiction in certain cases).

It may then be objected that this will deprive the federal courts of the initial opportunity to construe federal law. If, however, there is some paramount federal interest in an initial construction of some federal law, then Congress can vest the federal courts with exclusive jurisdiction over that law. Lockerty v. Phillips, 319 U.S. 182 (1943); The Moses Taylor, 71 U.S. (4 Wall.) 411 (1867). And the possibility of Supreme Court review of a misconstruction of federal law is always open. Martin v. Hunter's Lessee, 14 U.S. (1 Wheat.) 304 (1816); Frankfurter, Distribution of Judicial Power Between United States and State Courts, 13 Cornell L.Q. 489, 517 (1928). But see 1 M. Farrand, supra note 98, at 124-25; HART \& WECHSLER, supra note 67, at 11 (Madison argued that federal trial courts with original jurisdiction would be necessary to uphold federal rights).

If the federal courts' jurisdiction over the federal claim is exclusive, restrictive pendent jurisdiction may cause plaintiffs the hardship of choosing between their federal and state claims, Note, The Impact of Aldinger v. Howard on Pendent Party Jurisdiction, 125 U. PA. L. Rev. 1357, 1363-65 (1977). But this hardship is mitigated by the doctrine of collateral estoppel. Litigation of one of the claims would resolve many factual issues pertinent to the other claim as a matter of collateral estoppel. State of Maryland ex rel. Gliedman v. Capital Airlines, Inc., 267 F. Supp. 298 (D. Md. 1967); D. Louisell \& G. Hazard, Cases and Materials on Pleading and Procedure 672-76 (3d ed. 1973). State courts also give preclusive effect to the judgments and matters adjudicated in federal courts. See Degnan, Federalized Res Judicata, 86 YALE L.J. 741, 755-56 (1976). With these issues resolved, settlement of the other claim would seem likely.

Should the hardship created by the exclusivity of the federal claim demand a widened doctrine of ancillary jurisdiction? No principled reason appears for expanding ancillary jurisdiction beyond the "necessity" conception outlined at pp. 639-40 supra. Exclusivity of jurisdiction is equivalent to the situation where a plaintiff insists upon bringing his action in federal court and the defendant or some third party has a claim that cannot normally be heard in federal court. In that situation, federal jurisdiction will be expanded, but only to the extent necessary to protect the integrity of the federal courts' processes and ability to dispose of property in their control. See p. 640 supra. General notions of fairness and economy must be distinguished from the principles inhering in Article III.

Shakman, supra note 3 , at 266-68, 285, arrives at many of the same conclusions with respect to the judicial economy question. His reasons, however, are again very speculative. Id. at 267-68. He also believes that Congress has the power to confer broad pendent jurisdiction over purely state claims. Id. at 267, 284. This power is discussed and rejected in note 132 infra. Finally, he regards convenience as a "test" for pendent jurisdiction. Shakman, supra note 3, at 283 . Convenience is not a test, but a consideration that must be weighed in arriving at a test for pendent jurisdiction. The test proposed in this Note should minimize potential inconvenience. Nevertheless, even if some inconvenience results, the final ansyer to objections based upon concern for judicial economy is that these considerations do not justify violating the constitutional requirement of limited jurisdiction. 
imposed jurisdictional and procedural limitations would be honored. ${ }^{116}$ These include restrictions on the minimum amount in controversy and on the parties who may assert the right in the claims. ${ }^{117}$

Two examples illustrate the application of this test: first, claims are stated arising under the Constitution and state common law, and second, under a federal statute and a state statute.

Federal Constitution/state common law. A tenured professor at a state university is fired because he presented Marxist views to his classes. His contract provides that he may be fired only if he becomes physically unable to teach or is convicted of a crime. He brings suit in federal district court alleging violation of his contract and his right to free speech. The federal claim arises under the First and Fourteenth Amendments. ${ }^{118}$ The elements of the claim are state interference with speech, subject to a countervailing governmental interest. ${ }^{119}$ The state claim is based on the common law. The elements of breach of contract are a valid contract, due performance by plaintiff, and breach by the defendant. ${ }^{120}$

Federal jurisdiction should not extend to the state claim. The federal claim alleges the violation of a fundamental political right rooted in the Constitution. ${ }^{121}$ The state claim alleges the violation of a separate right rooted in the recognition that the law gives to a transaction between parties.122 The elements of the two claims assist the court in characterizing the rights and in determining the overlap between them. As shown by the complete difference between the elements of the two claims, the rights here do not overlap at all.

116. Even when sitting as a "state" court in diversity, the federal courts adhere to federal jurisdictional and procedural limitations. Hanna v. Plumer, 380 U.S. 460 (1965); Erie R.R. v. Tompkins, 304 U.S. 64 (1938).

117. E.g., Monroe v. Pape, 365 U.S. 167, 187-91 (1961) (question whether municipal corporations suable under $\S 1983$ to be answered by legislative history); see note 61 supra. It may be argued that, purely as a matter of statutory construction, the $\$ 10,000$ minimum should be deemed to be satisfied if there is at least one claim that exceeds $\$ 10,000$. The minimum amount in controversy is designed to insure that claims brought to the federal courts meet a threshold of substantiality, and when one claim meets this threshold, other pendent claims not meeting it should still be allowed since the attention of the federal court has been gained by the substantial claim. But see Zahn v. International Paper Co., 414 U.S. 291 (1973) (refusing to aggregate claims in diversity class action on pendent party theory without discussing pendent party jurisdiction). Under this Note's analysis, the state claim would also have to meet the statutory minimum. But since under this analysis the state and federal claims would be so closely related, it is difficult to imagine a case in which the state claim would not meet the statutory minimum.

118. See, e.g., Keyishian v. Board of Regents, 385 U.S. 589, 605-10 (1967) (right of association).

119. See, e.g., Konigsberg v. State Bar, 366 U.S. 36, 49-51 (1961).

120. F. JAMEs \& G. HAZARD, supra note 26, at 112.

121. See Palko v. Connecticut, 302 U.S. 319,326 (1937) (dictum).

122. A. Corbin, Corbin on Contracts 4-6 (1952). 
If, however, the professor's contract contained a term guaranteeing him "academic freedom," and a state court had construed this term as incorporating the right to free speech, then a breach of contract action would be within the pendent jurisdiction of the federal court. But jurisdiction over this contractual claim would not necessarily confer jurisdiction over other claims that might arise out of the contract. Jurisdiction would attach over such additional contractual claims only if they were substantially identical to the federal right originally asserted.

Federal statute/state statute. A group of milk producers contract to distribute all of their output through a wholesale milk distributor. The distributor then sells the milk to retailers. The distributor is obligated to pay the net proceeds of its sales to the producers. A state statute sets a minimum wholesale price for milk. The distributor, however, pays a rebate to retailers so that the effective wholesale price is below the statutory minimum.

The milk producers bring suit alleging a conspiracy in restraint of trade and a violation of the minimum price statute. The federal claim arises under the Sherman Act. ${ }^{123}$ A Sherman Act claim is stated because the producers allege a conspiracy affecting commerce that tends to restrain trade by encouraging state retailers to purchase less out-ofstate milk than they would normally purchase. ${ }^{124}$ Arguably, the reduced price that the producers receive is sufficient to give them standing to assert the Sherman Act claim. ${ }^{125}$ The state claim arises under the state minimum price statute. ${ }^{126}$ The state claim is made out by showing that the wholesale price is less than the statutory minimum. ${ }^{127}$ It is premised only on the violation of a statutory minimum price, not on a violation of a state version of the antitrust laws.

Federal jurisdiction should not extend to the state claim. The state right to a minimum price differs from the federal right to a competitive market. The elements of a Sherman Act violation are irrelevant to establishing a violation of the state statute. But if the state had passed an antirebate statute, and if the producers had brought a claim arising under it, then pendent jurisdiction would attach to this state

123. 15 U.S.C. $\$ 1$ (Supp. V 1975).

124. Knuth v. Erie-Crawford Dairy Coop. Ass'n, 395 F.2d 420 (3d Cir. 1968).

125. Id. at 424. The Knuth court did not discuss in any detail the difficult issues of standing under $\S 4$ of the Clayton Act, 15 U.S.C. $\$ 15$ (1970), which provides for private treble damage suits. See $395 \mathrm{~F} .2 \mathrm{~d}$ at 425 . These issues are beyond the scope of this Note. See generally Berger \& Bernstein, An Analytic Framework for Antitrust Standing, 86 YaLE L.J. 809 (1977).

126. E.g., PA. StAT. Ann. tit. 31, §700j-803 (Purdon Supp. 1977).

127. See Colteryahn Sanitary Dairy v. Milk Control Comm'n, 332 Pa. 15, 1 A.2d 775 (1938). 
claim. The elements of such a claim might be: (1) secrecy of the rebate; (2) failure to pay the rebate in like terms to all buyers; and (3) tendency to destroy competition. ${ }^{128}$ The state rebate claim would assert the violation of a right either encompassed within, or substantially identical to, the Sherman Act claim.

This example may also be used to illustrate the application of this Note's test to two common situations in which ancillary jurisdiction is now exercised. ${ }^{129}$ If the producers had secretly been selling part of their milk output to other wholesalers they would be violating their output contract. The distributor might state a breach of contract as a counterclaim. Since the counterclaim seeks to vindicate a contractual right different from the right to a competitive market, federal jurisdiction would not extend to this counterclaim. ${ }^{130}$ If, however, the distributor sought to implead a group of retailers as third-party defendants because they had engaged in a conspiracy to fix prices by forcing the payment of the rebates, federal jurisdiction would exist over this action. Buyers' price fixing is condemned by many state unfair competition laws. ${ }^{131}$ The impleader would be dependent on the right to a competitive market, the common nucleus of operative law in the original action. ${ }^{132}$

128. E.g., Baratti v. Koser Gin Co., 206 Ark. 813, 177 S.W.2d 750 (1944).

129. See note 95 supra (discussing present scope of ancillary jurisdiction).

130. Federal Rule 13(a) currently states that counterclaims are compulsory if the counterclaim arises out of the same transaction as the claim. FED. R. Civ. P. 13(a). This rule cannot be construed as permitting a transactional test for ancillary jurisdiction since it must be read with Rule 82 , which states that the Rules are not to be regarded as expanding federal jurisdiction. FED. R. Crv. P. 82. Within the boundaries of federal jurisdiction a transactional test for compulsory counterclaims is appropriate, but a counterclaim relying on state law should not be compulsory unless the law relied on is substantially the same as the law relied on in the federal claim.

131. E.g., AlA. Code tit. 8, \$ 8-10-1 (1975), construed in Dothan Oil Mill Co. v. Espy, 220 Ala. 605, 127 S. 178 (1930); cf. People v. Milk Exch., 145 N.Y. 267, 39 N.E. 1062 (1895) (common law).

132. Other examples might be:

Federal statute/state common law. A law publication is founded in Cambridge, Massachusetts. It calls itself the Yale Law Journal and distributes one issue. The actual Journal brings suit in federal district court alleging trademark infringement and unfair competition. The federal claim arises under the Lanham Trade-Mark Act, 15 U.S.C. $\$ \$ 1051$ 1127 (1970 \& Supp. V 1975). The elements of trademark infringement are the use in commerce of a registered trademark, without the owner's consent, such use being likely to confuse or deceive purchasers of the true origin of the goods. Id. $\S 1114(1)$. Actual intent to infringe need not be shown so long as the device is shown to be calculated to deceive. Tisch Hotels, Inc. v. Americana Inn, Inc., 350 F.2d 609, 613 (7th Cir. 1965).

The state claim is based on the common law. The elements of unfair competition are the simulation by one person of the tradenames, symbols, or devices employed by $a$ business rival in order to induce the purchase of goods under a false impression of their ownership. Brown \& Bigelow v. BB Pen Co., 191 F.2d 939, 943 (8th Cir. 1951). Actual intent need not be shown. Champion Spark Plug Co. v. Sanders, 331 U.S. 125 (1947). Federal jurisdiction should be extended over the state claim. In both claims the 


\section{Conclusion}

Article III provides the means by which rights secured by federal law are protected in the federal courts. A test for pendent jurisdiction that allows federal jurisdiction over state claims asserting essentially the same rights as those protected by federal law comports with the mandate of Article III. The substantial identity between the state and federal rights would still tie federal jurisdiction to federal law, and the congressional conferral of jurisdiction over the federal right would cover the substantially identical state right. Moreover, such a test would not constitute an infringement of state sovereignty or an intrusion into state law by federal courts, because of the congressional creation of federal rights essentially the same as state rights.

violation of a right to exclusive use of a tradename has been alleged. The elements of each are virtually the same.

It may also be said that in recognition of the closeness of such state and federal claims, Congress conferred jurisdiction over related state claims of unfair competition in 28 U.S.C. $\$ 1338$ (b) (1970). Under the analysis of Article III in this Note, however, see pp. 137-38 supra, Congress could not constitutionally confer jurisdiction over state claims that are merely factually related to federal claims. In addition to a congressional conferral of jurisdiction, Article III requires the existence of some law upon which the plaintiff can rely. It is this latter requirement that the test proposed in this Note supplies.

Federal Constitution/state statute. A police officer comes upon a covey of students who he believes are smoking marijuana. All members of the group flee, except for one student. The policeman clubs him into insensibility. It is later shown that the students were not smoking marijuana.

The student brings suit alleging assault and battery and the violation of his Fourteenth Amendment rights against the city that employs the policeman. The exact locus within the Constitution of the right to be free from police assault is unclear, but it is beyond question that a person who is assaulted by a state official can state a claim against the official under the Fourteenth Amendment. Fitzgerald v. Appolonia, 323 F., Supp. 1269, 1270 (E.D. Pa. 1971). The two requirements for such a claim are (1) a specific description of the wrong and (2) the state official's conduct must exceed negligence and constitute intentional misconduct or recklessness. Reed v. Philadelphia Housing Auth., 372 F. Supp. 686, 692 (E.D. Pa. 1974).

The assault and battery claim arises under the common law and a state statute waiving municipal immunity. E.g., Cook v. Clallam County, 27 Wash. 2d 793, 180 P.2d 573 (1947) (right to sue is statutory and is subject to legislative limitations); WASH. REv. CODE ANN. $\$ 4.08 .120$ (1962). The elements of assault and battery are well established, see W. Prosser, HaNdBook of THE LAw of Torts $\$ \$ 9,10$ (4th ed. 1971), and track with the Fourteenth Amendment claim. Most importantly, assault and battery cannot be predicated on negligence; actual intent or recklessness must be shown. $I d$. $\S 9$ at $35-37, \S 10$ at $40-41$.

Although both claims allege a violation of the same right to be free from bodily harm, municipalities have been excluded from the class of parties who may be sued for the deprivation of due process rights. Monroe v. Pape, 365 U.S. 167, 187-91 (1961). Federal jurisdiction should not extend over either claim against the municipality. If the student had also brought state and federal claims against the policeman, however, then pendent jurisdiction would attach to the state claim against the policeman. State officials are clearly liable for the deprivation of such rights.

The examples in text and this footnote appear most frequently in the case law. Other combinations are also possible: federal Constitution/state constitution; federal statute/ state constitution; and treaty/state constitution, statute, or common law. 
A restriction on pendent jurisdiction would also be wise judicial policy. As Justice Frankfurter noted, the federal courts, like all courts, exist to secure justice. ${ }^{133}$ They must, therefore, be efficiently organized. But total efficiency would endow the federal courts with general jurisdictional powers, and they would displace the state courts as interpreters of the law governing private activity. Unlike courts of general jurisdiction, the federal courts also serve a political functionthey help to effect the adjustments upon which life in a federated nation depends. ${ }^{134}$ The jurisdiction of the federal courts must therefore be determined not only by considerations of efficiency, but also by the relationship of states to nation. The Gibbs Court disregarded this political function in the name of judicial efficiency. A more limited test for pendent jurisdiction would commit the federal courts to their proper constitutional role.

133. Frankfurter, Distribution of Judicial Power Between United States and State Courts, 13 CORNELl L.Q. 499, 500 (1928).

134. Id. 